\title{
CASE STUDY OF A MANGANESE AND IRON PRECIPITATE IN A GROUND-WATER DISCHARGE IN SOMERO, SOUTHWESTERN FINLAND
}

\author{
LIISA CARLSON, TAPIO KOLJONEN, \\ PERTTI LAHERMO, and ROLF J. ROSENBERG
}

\begin{abstract}
CARLSON LIISA, KOLJONEN TAPIO, LAHERMO PERTTI, and ROSENBERG ROLF J. 1977: Case study of a manganese and iron precipitate in a groundwater discharge in Somero, southwestern Finland. Bull. Geol. Soc. Finland 49 (2): 159-173.
\end{abstract}

\begin{abstract}
A study was made of the mineral and chemical composition of a concentric precipitate formed around a ground-water discharge, where manganese had precipitated before iron. Birnessite was identified in the Mn-rich precipitate and goethite and lepidocrocite in the Ferich precipitate. Lepidocrocite is typically crystallized in hydromorphic soils where $\mathrm{Fe}$ is reduced. $\mathrm{Ti}$ and $\mathrm{Cr}$ are enriched more in the Fe-rich than in the Mn-rich precipitate, while the reverse is true for $\mathrm{Ni}$ and $\mathrm{Cu}$. The $\mathrm{K} / \mathrm{Rb}$ ratio is higher $(790-3000)$ than in common rock types $(160-300)$. This indicates the incorporation of $\mathrm{K}$ into the minerals formed, whereas $\mathrm{Rb}$ is withheld in the precipitate by adsorption. The total content of REE is increased in the precipitate studied but is lower than in oceanic Mn nodules. The La/Yb ratio is higher than usual in continental rock types, which indicates slower migration of the light REE (La-Sm) than of the heavy $(\mathrm{Gd}-\mathrm{Lu})$. Compared with the other $\mathrm{REE}, \mathrm{Ce}$ is enriched in many continental oxidates, though not in the young oxidates studied here. Probably because $\mathrm{Ce}$ is oxidized to valence $4+$, it is chemically and through adsorption bound more strongly to precipitates than the other REE with valence $3+$ and enriched upon partial dissolution. This suggests that the trace element composition of $\mathrm{Mn}$ and $\mathrm{Fe}$ precipitates largely comes about through the partial dissolution of the original precipitate.
\end{abstract}

Liisa Carlson and Tapio Koljonen," Department of Geology, University of Helsinki, P.O. Box 115, SF-00171 Helsinki 17, Finland.

Pertti Lahermo, Geological Survey of Finland, SF-02150 Espoo 15, Kivimiehentie 1, Finland.

Rolf J. Rosenberg, Reactor Laboratory, Technical Research Centre of Finland, SF-02150 Espoo 15, Finland.

* Address until 2. 11. 1979: University of Dar es Salaam, Department of Geology, P.O. Box 35602, Dar es Salaam, Tanzania.

\section{Introduction}

This paper is a part of a comprehensive investigation designed to elucidate the exogenic geochemical cycle of manganese and iron in northern Europe. A concentric $\mathrm{Mn}$,
Fe precipitate formed around a ground-water discharge as cement in glaciofluvial sand is described and its mineral and chemical composition is presented and discussed. A study of the iron minerals and the trace element and especially the rare earth element (REE) 


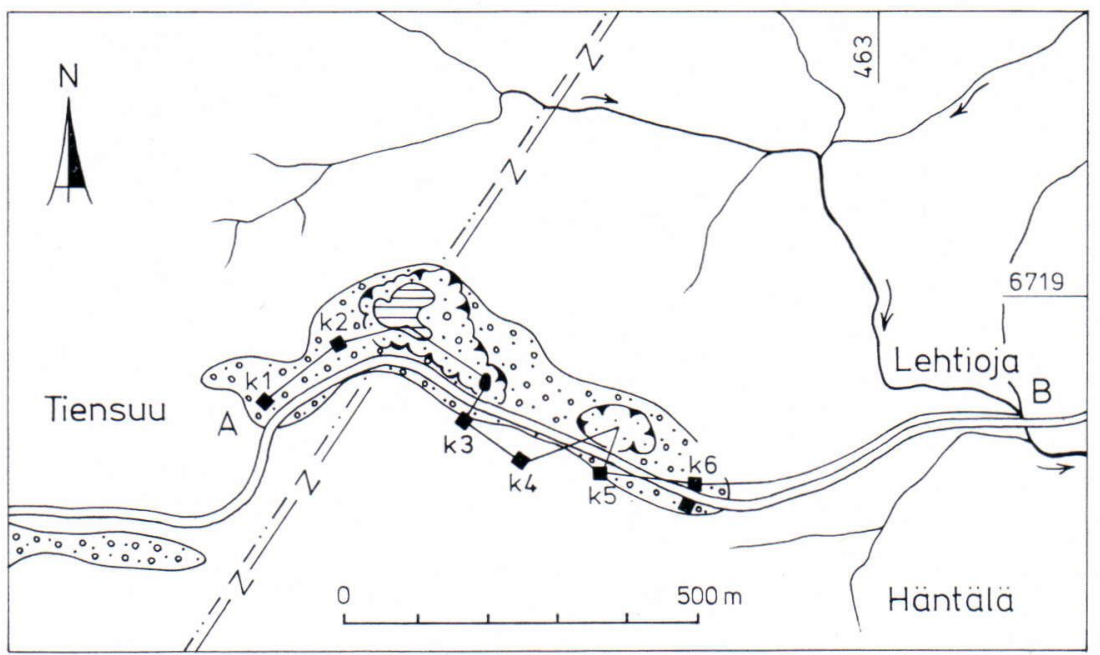

Fig. 1. Location of the gravel pit with Mn, Fe precipitate. Symbols as in Fig. 2.

contents is Fennoscandian oxidate sediments is presently underway.

The principles of precipitation of manganese and iron in Fennoscandia are discussed. by Carlson et al. (in press), and case histories of precipitation in glaciofluvial material are presented by Låg (1960), Vasari et al. (1972), Alhonen etal. (1975), and Koljonen et al. (1976). The last paper also lists the most common morphological types of precipitates.

\section{Description of the surroundings}

The studied manganese and iron precipitate lies at the bottom of a gravel pit in Häntälä esker, $12 \mathrm{~km} \mathrm{S.W.} \mathrm{of} \mathrm{Somero,} \mathrm{S.W.} \mathrm{Finland}$ (Fig. 1). The area is characterized by a flat clay terrain interrupted by partly till-covered rocky hills and 20-35 m-deep erosional creek and river valleys (e.g., Lehtioja Creek, Figs. 1 and 2). The esker is typically longitudinal and in many places broken or covered by clay deposits.

Häntälä esker is composed of glaciofluvial sand and gravel, the deeper parts usually being coarser than the mantle and skirts.
Although the esker chain is often covered with clay, in some places there is hydraulic continuity for several kilometers, with the ground water flowing in the east-northeast direction of the esker towards the valley of Lehtioja Creek. Its position as levelled via dug wells and some ground-water outcrops is presented in the longitudinal profile $\mathrm{C}-\mathrm{D}$ (Fig. 2).

The studied $\mathrm{Mn}, \mathrm{Fe}$ precipitate is formed in a place where the ground-water table is some twenty or thirty centimeters below the surface of the gravel pit and where it abruptly descends, forming an underground »waterfall» (Fig. 2, Profile C-D). The peculiar, more or less circular form of the precipitate (Fig. 3) is a result of piping caused by discharging ground water at the bottom of the gravel pit. The same kind of continuous piping without precipitation often occurs in sand and fine sand at the bottom of natural springs. The circles diminish in size downwards to give a funnel-like structure.

The material is somewhat finer inside the funnel than nutside (see Fig. 3). Inside it is sorted concentric, the material of finest grain 


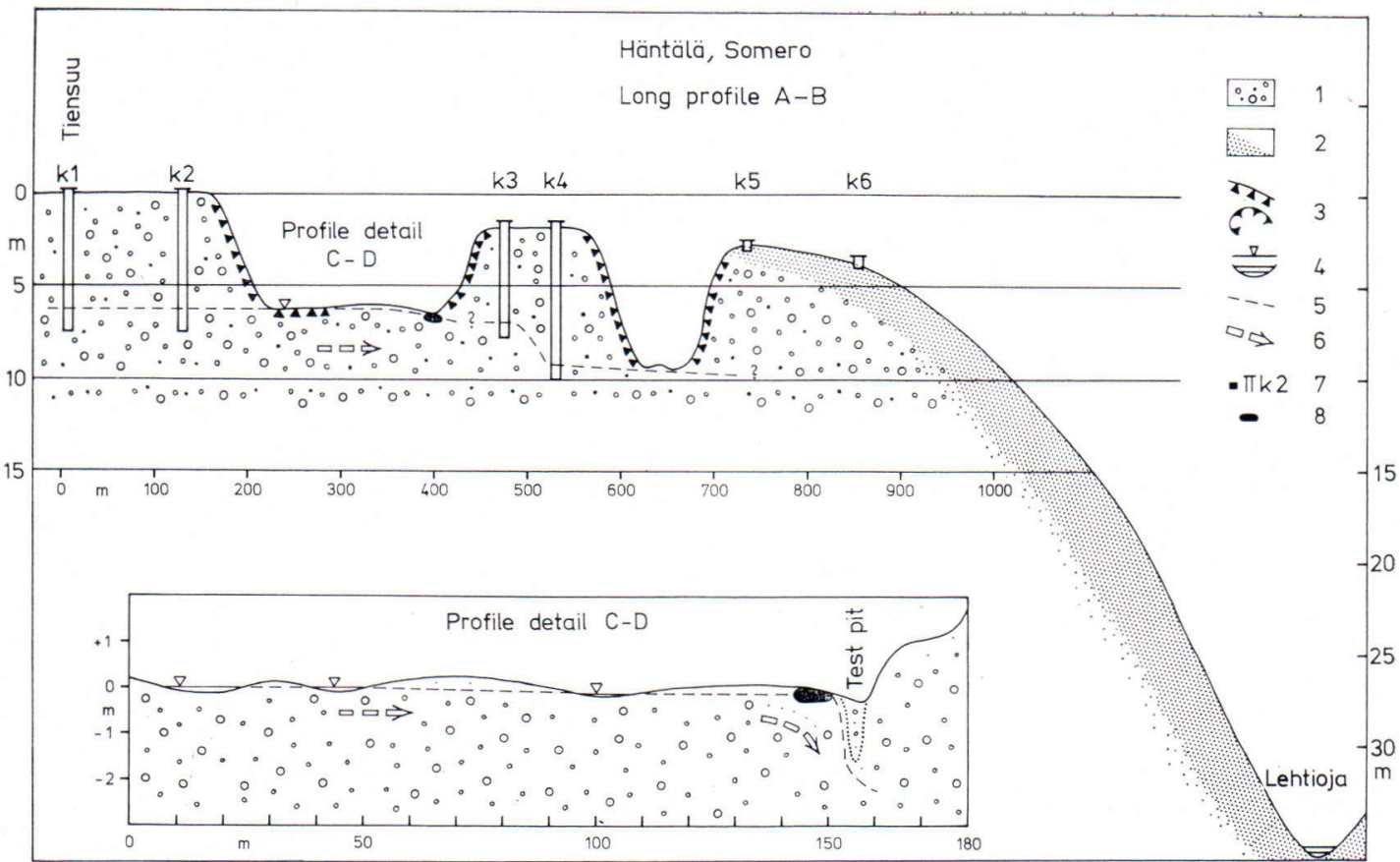

Fig. 2. Long profile through the Häntälä esker anł a profile detail through the gravel pit with Mn, Fe precipitate (cf., Fig. 1). (1) Gravel and sand; (2) Silt and clay; (3) Slope; (4) Recently outcropping ground-water table; (5) Ground-water table; (6) Direction of ground-water flow; (7) Dug well (levelled ground-water table); (8) Mn, Fe precipitate.

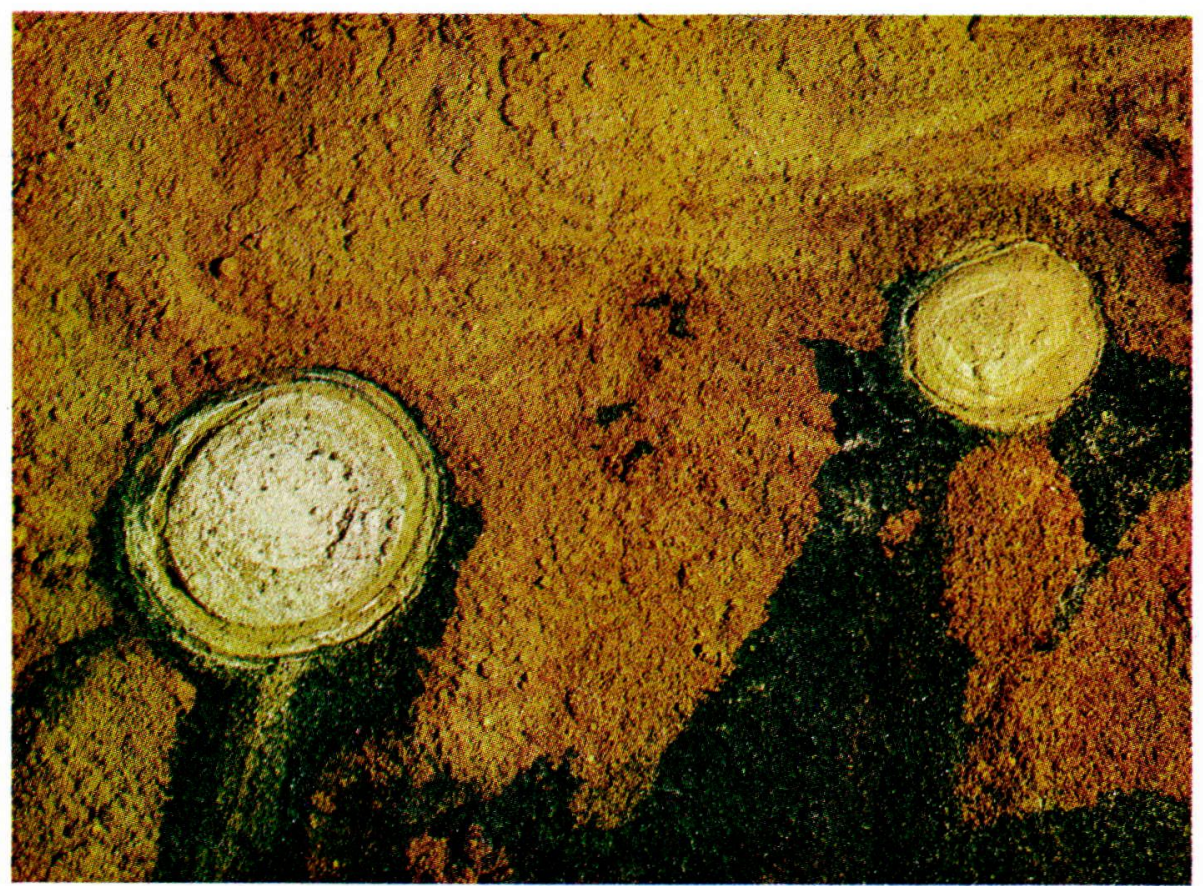

Fig. 3. The circular Mn, Fe precipitate (horizontal section). The diameter of the smaller circle is $14 \mathrm{~cm}$. 


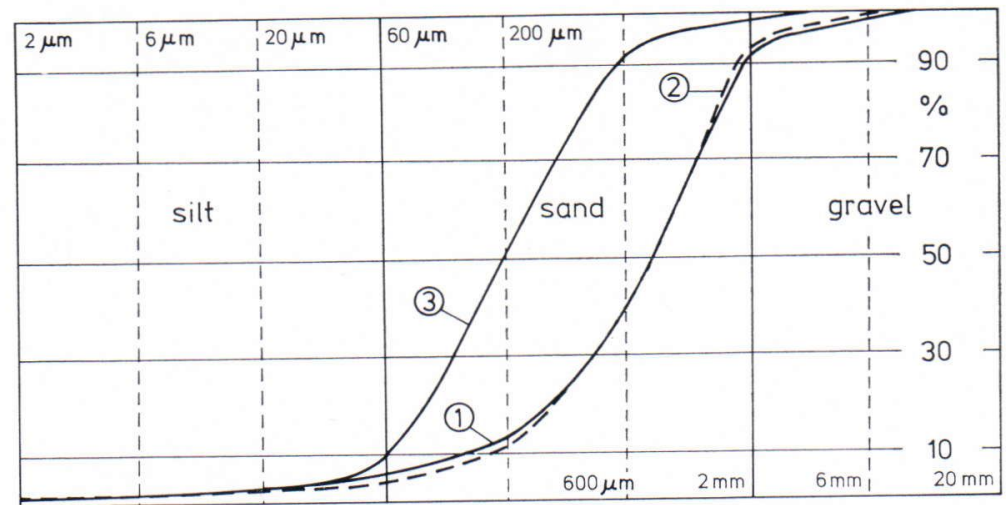

Fig. 4. Grain-size distribution of esker material. (1) Sand with Mn-rich precipitate (2 samples); (2) Sand with Fe-rich precipitate (broken line, 3 samples); (3) Sand without precipitate (2 samples).

size being sometimes in the centre and sometimes in the outer parts in the form of distinct haloes. Differences in the texture of esker material favor the selective precipitation of $\mathrm{Mn}$ and $\mathrm{Fe}$, Mn usually being precipitated in more coarse-grained material than Fe (Koljonen et al. 1976). In the precipitate studied, however, there is no distinct difference in texture between material with $\mathrm{Mn}$ and material with Fe precipitate (Fig. 4, curves 1 and 2). Material without any cement is finer (curve 3 ).

The precipitate has been formed in a recently opened gravel pit, and cannot be more than about $10-15$ years old.

Samples for analysis of the precipitate were collected from the innermost part of the Mn-rich cement, just outside the funnel (Table 3, No. 1), and from differently colored parts of the Fe-rich cement $1 \mathrm{~m}$ (No. 2) and 2 m (No. 3) from sample No. 1. Water samples were collected from the bottom of the gravel pit (No. 4).

Ground water in the Häntälä esker close to the precipitate is slightly acidic to neutral (arithmetic mean of $\mathrm{pH}$ values $6.9,5$ analyses) and contains small amounts of dissolved electrolytes (specific conductivity $61 \mu \mathrm{S} / \mathrm{cm}, 5$ analyses, and total hardness $1.9^{\circ} \mathrm{dH}, 4$ anal- yses). The $\mathrm{Mn}$ and $\mathrm{Fe}$ content varies considerably (Table 3, No. 4) and is especially low where the ground-water table outcrops. The $\mathrm{Mn} / \mathrm{Fe}$ ratio varies between 0.007 and 0.03 (5 analyses).

\section{Methods}

The precipitates were concentrated and minerals in unheated and heated samples identified by the X-ray diffraction method as described in Koljonen et al. (1976). A Philips diffractometer operating with $\mathrm{FeK}_{\alpha}$ radiation was used. The recrystallization at elevated temperatures was further studied by analysing the samples both thermally (DTA) and thermogravimetrically (TG) with a Rigaku Denki high temperature apparatus. The heating rate was $5^{\circ} \mathrm{C} / \mathrm{min}$.

The color of the precipitates was measured by comparison of the air-dried concentrated samples with Munsell Soil Color Charts (1975).

For chemical analysis the concentrated precipitates were dissolved in $\mathrm{HNO}_{3}$ and $\mathrm{H}_{2} \mathrm{O}_{2}$. $\mathrm{Mn}$ was determined colorimetrically, Fe by titration with $\mathrm{K}_{2} \mathrm{CrO}_{7}$, and $\mathrm{Al}, \mathrm{Mg}, \mathrm{Ca}$, $\mathrm{K}, \mathrm{Na}, \mathrm{Ti}, \mathrm{Sn}, \mathrm{Pb}, \mathrm{Cr}, \mathrm{Ni}, \mathrm{Co}, \mathrm{Zn}, \mathrm{Cu}, \mathrm{Cd}, \mathrm{Rb}$, and Li by AAS (Perkin Elmer 404). 
Table 1. Some data for the analysis of REE.

\begin{tabular}{|c|c|c|c|c|}
\hline $\begin{array}{l}\text { Irradiation } \\
\text { time }\end{array}$ & Decay time & Detector & $\begin{array}{l}\text { Measurement } \\
\text { time }\end{array}$ & $\begin{array}{l}\text { Elements } \\
\text { determined }\end{array}$ \\
\hline $\begin{array}{l}5 \mathrm{~min} \\
7 \mathrm{~h}-30 \mathrm{~h} \\
7 \mathrm{~h}-30 \mathrm{~h}\end{array}$ & $\begin{array}{l}0.5 \mathrm{~h}-4 \mathrm{~h} \\
4 \mathrm{~d}-7 \mathrm{~d} \\
\text { ca. } 6 \text { weeks }\end{array}$ & $\begin{array}{l}\text { small } \\
\text { large } \\
\text { small }\end{array}$ & $\begin{array}{l}10 \mathrm{~min}-20 \mathrm{~min} \\
0.5 \mathrm{~h}-2 \mathrm{~h} \\
2 \mathrm{~h}-4 \mathrm{~h}\end{array}$ & $\begin{array}{l}\text { Dy } \\
\text { La, Sm, Lu } \\
\text { Ce, Nd, Eu, } \\
\text { Gd, Tb, Yb }\end{array}$ \\
\hline
\end{tabular}

The method of instrumental neutron activation analysis of ten REE is briefly as follows (see Rosenberg 1977): Standards are prepared by dissolution of oxides in $\mathrm{HNO}_{3}$, and in the case of $\mathrm{CeO}_{2}$, in a mixture of $\mathrm{HNO}_{3}$ and $\mathrm{H}_{2} \mathrm{O}_{2}$. The stock solutions are then mixed to give a composite standard comprising all the REE studied, in concentrations approximately the same as in basalt.

Homogenized and pulverized samples (100 mg - $300 \mathrm{mg}$ ) and standards are weighed in $0.5 \mathrm{ml}$ polyethylene capsules for the analysis of Dy and in $70 \mathrm{~mm} \times \varnothing 6 \mathrm{~mm}$ quartz ampoules for the determination of the other REE. The samples, together with the standards, are irradiated, left to decay, and their $\gamma$-spectra measured (see Table 1). The irradiation of $5 \mathrm{~min}$ is performed in a thermal neutron flux of $1.2 \times 10^{12} \mathrm{~cm}^{-2} \mathrm{~s}^{-1}$ and the irradiation of $7 \mathrm{~h}-30 \mathrm{~h}$ in a thermal neutron flux of $10^{13} \mathrm{~cm}^{-2} \mathrm{~s}^{-1}$. The $\gamma$-spectra are measured with a $\gamma$-spectrometer equipped with one of two detectors, a sample changer, and a Nuclear Data 4410 pulse height analyser. The detectors are a small Ortec $5 \mathrm{~mm} \times \varnothing 10 \mathrm{~mm} \mathrm{Ge}(\mathrm{Li})$-detector with a resolution of $550 \mathrm{eV} \mathrm{FWHM} \mathrm{at} 122 \mathrm{keV}$ and a large Ortec $\mathrm{Ge}(\mathrm{Li})$-detector with a relative efficiency of $10 \%$ and a resolution of $2 \mathrm{keV}$ FWHM at $1332 \mathrm{keV}$. The measured spectra are punched on paper tape and analysed with a computer program written for a UNIVAC 1108 computer. The program calculates the elemental concentrations in the samples.

The isotopes and the corresponding $\gamma$ energies used for the calculation are shown in Table 2. In some cases interfering activ-

Table 2. Half-lives of the isotopes, $\gamma$-rays used, interfering activities, and detection limits of the elements determined.

\begin{tabular}{|c|c|c|c|c|}
\hline Isotope & Half-life & $\begin{array}{c}\gamma \text {-energy } \\
(\mathrm{keV})\end{array}$ & $\begin{array}{l}\text { Subtracted } \\
\text { interference }\end{array}$ & $\begin{array}{c}\text { Detection } \\
\text { limit } \\
\text { (ppm) }\end{array}$ \\
\hline $\begin{array}{l}140 \mathrm{La} \\
141 \mathrm{Ce} \\
147 \mathrm{Nd} \\
153 \mathrm{Sm} \\
152 \mathrm{Eu} \\
153 \mathrm{Gd} \\
160 \mathrm{~Tb} \\
165 \mathrm{Dy} \\
169 \mathrm{Yb} \\
208 \mathrm{Lu}\end{array}$ & $\begin{array}{cc}40.27 & \mathrm{~h} \\
32.5 & \mathrm{~d} \\
11.1 & \mathrm{~d} \\
47.1 & \mathrm{~h} \\
12.2 & \mathrm{a} \\
236 & \mathrm{~d} \\
73 & \mathrm{~d} \\
2.36 & \mathrm{~h} \\
30.6 & \mathrm{~d} \\
6.75 & \mathrm{~d}\end{array}$ & $\begin{array}{r}1595.4 \\
145.4 \\
91.4 \\
103.2 \\
121.8 \\
103.2 \\
86.8 \\
94.6 \\
63.1 \\
208.4\end{array}$ & $\begin{array}{lcc}233 \mathrm{~Pa} & 103.8 \mathrm{keV} \\
233 \mathrm{~Pa} & 87 & \mathrm{keV}\end{array}$ & $\begin{array}{l}0.5 \\
2 \\
5 \\
0.06 \\
0.05 \\
4 \\
0.05 \\
0.3 \\
0.07 \\
0.2\end{array}$ \\
\hline
\end{tabular}


ities had to be subtracted. The detection limits indicated in Table 2 are valid for basaltic rock type and as an order of magnitude for the other common rock types. Because the sensitivity of the method depends on the concentrations of certain other elements in the sample, the detection limits for different samples vary considerably. Thus the detection limit for Dy is inversely proportional to the concentration of $\mathrm{Mn}$ and the detection limits of $\mathrm{Tb}$ and Gd correspondingly to the concentration of $\mathrm{Th}$ producing the interfering isotope ${ }^{233} \mathrm{~Pa}$. The average precision of single determinations is $13 \%$. Because of the lack of significant systematic errors the accuracy is of the same magnitude.

\section{Mineral composition}

Manganese precipitate. Birnessite is the only Mn-mineral identified in the Mn precipitate by X-ray diffraction (Fig. 5; for chemical composition see Table 3 , No. 1 ). It is a non-stoichiometric manganese oxyhydroxide which may contain various amounts. of other cations, e.g., $\mathrm{Mg}, \mathrm{Ca}, \mathrm{K}$, and $\mathrm{Na}$ depending among other things on the cations present upon crystallization. Mn-precipitates deposited by natural waters contain considerable amounts of Fe (Table 3; Koljonen et al. 1976, Table 2; Carlson et al., in press, Table 3). Because no iron oxyhydroxide mineral is shown in the X-ray graph (Fig. 5; Koljonen et al. 1976) it can be assumed that $\mathrm{Fe}$ is present in the form of ferrihydrite, i.e. »amorphous» $\mathrm{FeOOH}$, as proposed by Giovanoli and Bürki (1975) in the context of oceanic Mn nodules.

Birnessite is a group name for synthetic and natural minerals, fine-grained and often disordered, with an $\mathrm{O} / \mathrm{Mn}$ ratio from 1.74 to 1.99 (Bricker 1965). It is common both in continental Mn-precipitates (Taylor et al. 1964, Taylor and McKenzie 1966, Taylor 1968, Koljonen et al. 1976) and in oceanic Mn

Table 3. Chemical composition of the $\mathrm{Mn}$, Fe precipitate and of ground and surface water in the studied area (1) Loose black cement (color 5YR 3/1); (2) Loose brown cement (7.5YR 4/6); (3) Loose brown cement (7.5YR 5/8); (4) Water on the bottom of the gravel pit; mostly 5 samples. Analyst (1-3) Antti Vuorinen, University of Helsinki and (4) Hilkka Ahola, Hannele Spetz, and Iaija Ilmasti, Geological Survey of Finland.

\begin{tabular}{|c|c|c|c|c|}
\hline & 1 & 2 & 3 & 4 \\
\hline $\mathrm{Mn}$ & $50.38 \%$ & $0.98 \%$ & $0.32 \%$ & $0.005-0.15 \mathrm{ppm}$ \\
\hline $\mathrm{Fe}$ & 3.50 & 51.92 & 38.33 & $0.7-5.0$ \\
\hline $\mathrm{Al}$ & 1.12 & 2.38 & 7.09 & $0.6-1.0$ \\
\hline $\mathrm{Mg}$ & 1.36 & 0.48 & 5.67 & $\begin{array}{ll}2.9 & -3.9\end{array}$ \\
\hline $\mathrm{Ca}$ & 2.15 & 0.23 & 1.19 & $5.0-9.8$ \\
\hline $\mathrm{K}$ & 1.70 & 2.61 & 2.09 & $1.3-2.0$ \\
\hline $\mathrm{Na}$ & 0.07 & 0.11 & 0.23 & $2.5-5.8$ \\
\hline $\mathrm{Ti}$ & 0.12 & 0.14 & 0.93 & - \\
\hline $\mathrm{Sn}$ & $750 \mathrm{ppm}$ & $<640$ ppm & $690 \mathrm{ppm}$ & - \\
\hline $\mathrm{Pb}$ & 120 & 200 & 170 & $<1$ ppb \\
\hline $\mathrm{Cr}$ & 30 & 180 & 280 & $<1$ \\
\hline $\mathrm{Ni}$ & 1140 & 184 & 120 & $<2$ \\
\hline Co & 144 & 190 & 130 & $<2$ \\
\hline $\mathrm{Zn}$ & 330 & 328 & 464 & $3-14$ \\
\hline $\mathrm{Cu}$ & 410 & 126 & 127 & 2 \\
\hline $\mathrm{Cd}$ & 17.7 & 11.0 & 12.7 & $<0.5$ \\
\hline $\mathrm{Rb}$ & 21.5 & 8.7 & 17.0 & - \\
\hline $\mathrm{Li}$ & 108 & 12 & 120 & - \\
\hline $\mathrm{K} / \mathrm{Rb}$ & 790 & 3000 & 1230 & - \\
\hline
\end{tabular}




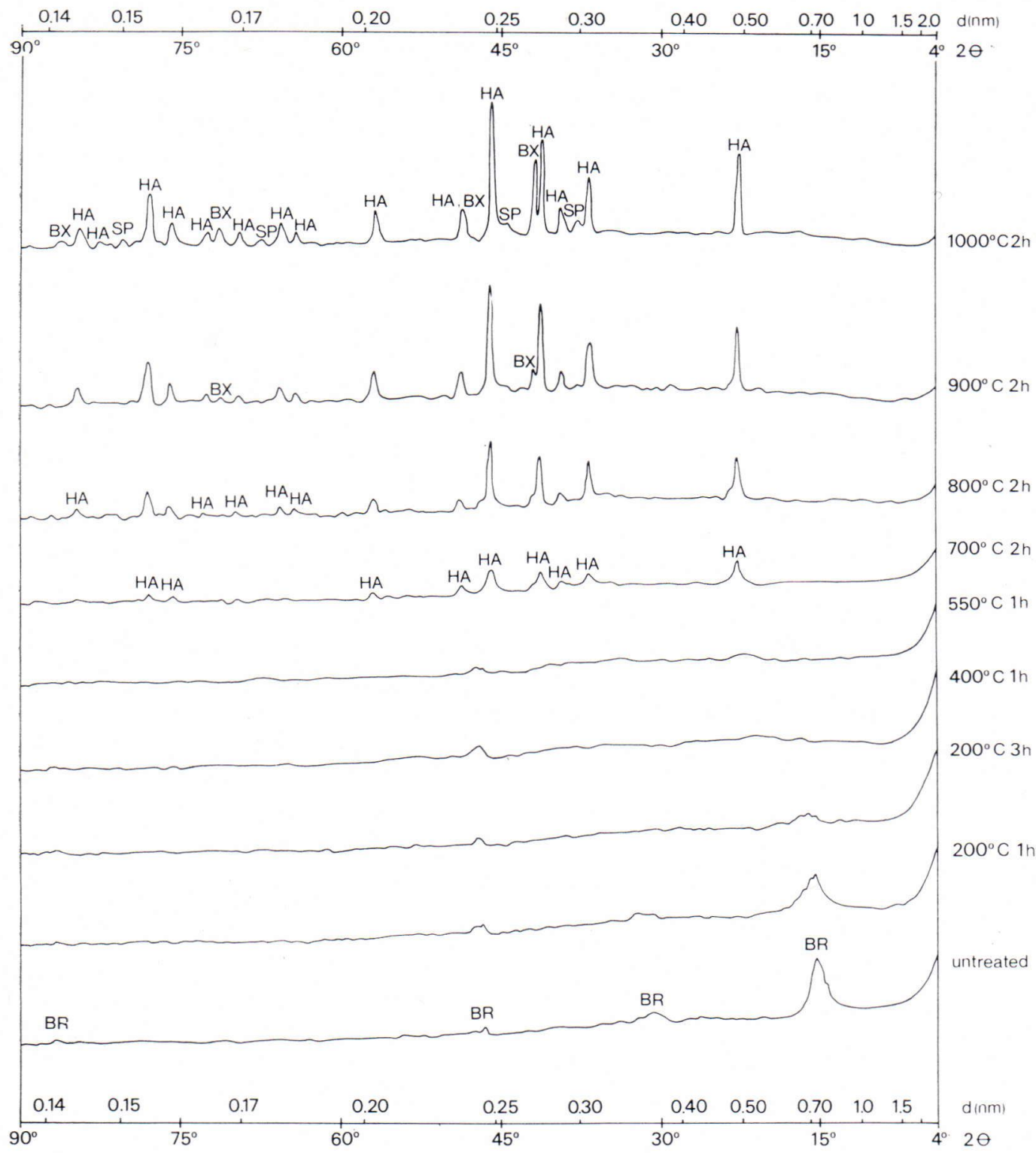

Fig. 5. X-ray data of unheated and heated Mn presipitate (Table 3, No. 1). BR, birnessite; HA, hausmannite; BX, bixbyite; SP, spinel. The graph is explained in the text.

nodules (e.g., Crerar and Barnes 1974, soils (Koljonen et al. 1976, Ross et al. 1976); Summerhayes and Willis 1975, Glover 1977). in the present case the ground water that The crystallization of birnessite is controlled deposits $\mathrm{Mn}$ is almost neutral. In oceanic by the redox conditions of the environment. Mn nodules birnessite is crystallized in more It is known to be crystallized in slightly oxidizing conditions than »todorokite» (Crerar alkaline (Taylor et al. 1964) to slightly acidic and Barnes 1974, Summerhayes and Willis 
1975) which according to Giovanoli and Bürki (1975) is a mixture of buserite and minor amounts of birnessite and manganite.

The typically very fine-grained birnessite is supposed to crystallize instead of the thermodynamically stable pyrolusite $\left(\beta-\mathrm{MnO}_{2}\right)$ because of its lower nucleation energy (Crerar and Barnes 1974). Besides kinetics, also the foreign cations present in natural waters favor its crystallization (Koljonen et al. 1976).

Information about the structure of birnessite (synthetic: sodium manganese(II,III) manganate(IV) and manganese(III) manganate(IV)) has been derived from electron diffraction measurements because efforts to prepare large enough crystals for single crystal X-ray methods were not successful (Giovanoli et al. 1970a, b; Giovanoli and Stähli 1970). The structure comprises layers of edge-shared $\left[\mathrm{MnO}_{6}\right]$ octahedra with sheets of water molecules and hydroxyl groups located between. One out of every six octahedral sites of $\mathrm{Mn}^{4+}$ is unoccupied, and $\mathrm{Mn}^{3+}$ and $\mathrm{Mn}^{2+}$ ions are considered to lie above and below these vacancies. The layers of $\left[\mathrm{MnO}_{6}\right]$ octahedra are separated by about $0.72 \mathrm{~nm}$ along the c-axis. The positon of other cations in the intermediate layer is uncertain. The crystal structure is basically hexagonal, but other cations, e.g. $\mathrm{Na}^{+}$, as lattice constituents, cause a distortion to at least orthorhombic structure (Giovanoli and Stähli 1970). Natural birnessite, whose alkali ions cannot be dissolved, gives the hexagonal X-ray pattern (Giovanoli etal. 1970b) because of the disordered crystal structure. The hexagonal indices of the four lines typical of natural birnessite (Jones and Milne 1956, Brown et al. 1971) are: $0.728 \mathrm{~nm}-001,0.363 \mathrm{~nm}-002$, $0.245 \mathrm{~nm}-100$, and $0.1414 \mathrm{~nm}-110$ (cf., Koljonen et al. 1976, Table 5).

Upon heat treatment the $\mathrm{Mn}$ precipitate is dehydrated corresponding to the broad endothermic reaction between $80^{\circ} \mathrm{C}$ and $250^{\circ} \mathrm{C}$ recorded by DTA. As the water molecules and hydroxyl groups are expelled from between the octahedral layers of birnessite the latter are gradually cleaved to form a two-dimensional lattice. On the X-ray graph the basal reflections $(0.728 \mathrm{~nm}$ and $0.363 \mathrm{~nm})$

Table 4. REE contents in Mn and Fe precipitates. The numbers $1-3$ indicate samples in Table 3 ; (5) Average REE contents in $13 \mathrm{Mn}$ and $\mathrm{Fe}$ precipitates from Fennoscandia; (6) Average REE contents in 31 oceanic Mn nodules (Piper 1974); (7) REE content in Leedey L/6 chrondrite (Masuda et al. 1973). The values in parentheses are estimates.

\begin{tabular}{|c|c|c|c|c|c|c|}
\hline No. & 1 & 2 & 3 & 5 & 6 & 7 \\
\hline $\mathrm{La}$ & 123 & 123 & 79 & 71 & 226 & 0.378 \\
\hline $\mathrm{Ce}$ & 138 & 240 & 185 & 221 & 722 & 0.976 \\
\hline $\operatorname{Pr}$ & - & - & - & - & - & $(0.138)$ \\
\hline $\mathrm{Nd}$ & 64 & 81 & 59 & 49 & 221 & 0.716 \\
\hline $\mathrm{Sm}$ & 12 & 14 & 9.4 & 8.5 & 44 & 0.230 \\
\hline $\mathrm{Eu}$ & 2.3 & 2.7 & 2.4 & 1.6 & 9.6 & 0.0866 \\
\hline Gd & 5.7 & 13 & - & 6.6 & - & 0.311 \\
\hline $\mathrm{Tb}$ & 1.4 & 1.6 & 1.3 & 1.0 & 7.5 & $(0.0568)$ \\
\hline Dy & - & 3.6 & 5.5 & - & - & 0.390 \\
\hline Ho & - & - & - & - & - & $(0.0868)$ \\
\hline Er & - & - & - & - & - & 0.255 \\
\hline $\mathrm{Tm}$ & - & - & - & - & - & $(0.0399)$ \\
\hline$Y d$ & 3.2 & 3.0 & 3.5 & & 20.2 & 0.249 \\
\hline $\mathrm{Lu}$ & 0.73 & 0.95 & 0.55 & 0.44 & 3.5 & 0.0387 \\
\hline$\sum \mathrm{REE}$ & 389 & 506 & 376 & 387 & 1445 & 3.95 \\
\hline $\mathrm{La} / \mathrm{Yb}$ & 38 & 41 & 23 & 32 & 11 & 1.5 \\
\hline
\end{tabular}




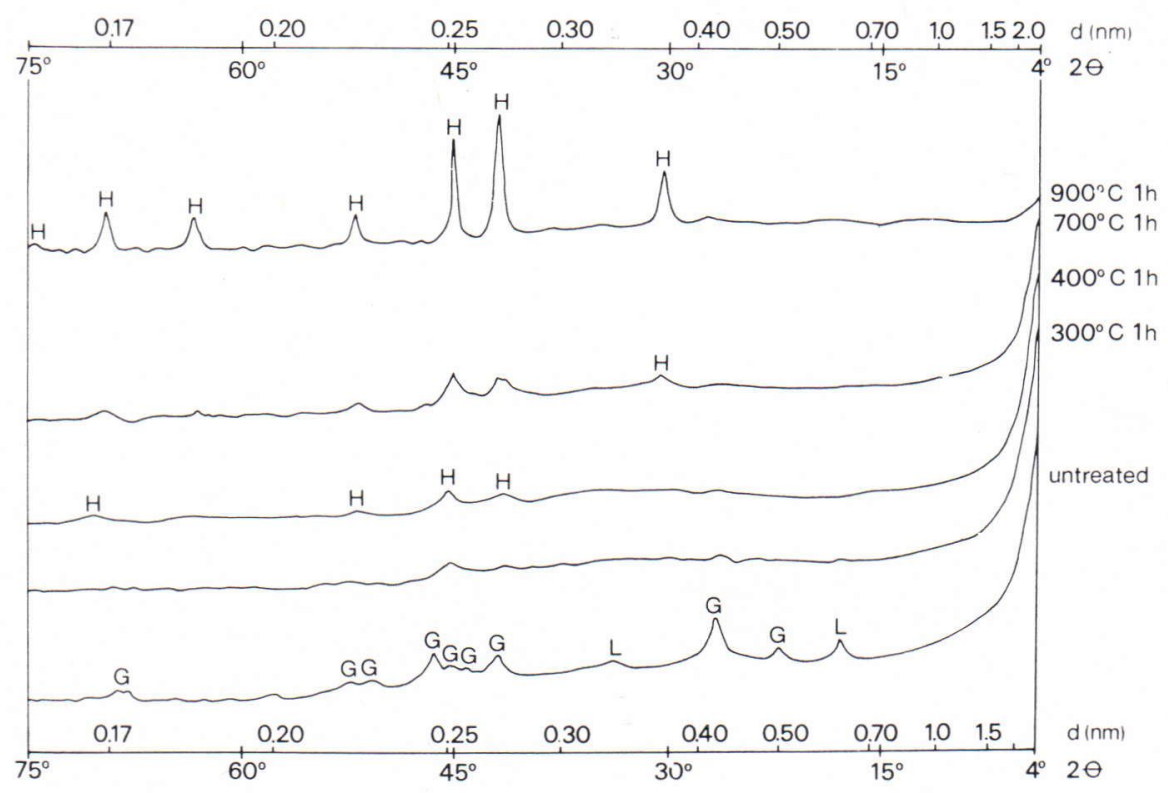

Fig. 6. X-ray data of unheated and heated Fe precipitate (Table 3, No. 2). G, goethite; L, lepidocrocite; $\mathrm{H}$, hematite. The graph is explained in the text.

first become weak and diffuse and shift to smaller d-values, and then gradually disappear as the temperature is elevated (Fig. 5) The two prism reflections are left and shifted to slightly smaller d-values (the 100 reflection of birnessite from $0.2455 \mathrm{~nm}$ to $0.2440 \mathrm{~nm}$ ). These lines represent octahedral $\mathrm{Mn}-\mathrm{Mn}$ distances common to almost all $\mathrm{Mn}-\mathrm{O}$ compounds (Giovanoli and Bürki 1975), and cannot be assigned to any particular mineral species. Probably only fragments of octahedral layers are left and the crystals of the new minerals formed are too small to give an X-ray diffraction pattern.

Hausmannite $\left(\mathrm{Mn}_{3} \mathrm{O}_{4}\right)$ crystals are large enough to be recorded by $\mathrm{X}$-ray diffraction after two hours at $700^{\circ} \mathrm{C}$ (Fig. 5). At still higher temperatures $\mathrm{Fe}$ and other cations are also involved in crystallization. Bixbyite $\left((\mathrm{Mn}, \mathrm{Fe})_{2} \mathrm{O}_{3}\right)$ was recorded at $900^{\circ} \mathrm{C}$ and a spinel at $1000^{\circ} \mathrm{C}$. This order of recrystallization is typical of Mn precipitates relatively poor in Fe (Table 3, No. 1; see Koljonen et al.
1976). With rising temperature the minerals become better crystallized and no interconversions seem to occur. The crystallizations are simultaneous and so sluggish until ca. $1160^{\circ} \mathrm{C}$ that no reaction was recorded by DTA. At $1160^{\circ} \mathrm{C}$ the tetragonal low hausmannite was transformed to the cubic high hausmannite (van Hook and Keith 1958), a reaction known to be rapid (Muan and Somiya 1962). The TG curve shows a continuous weight loss between $100^{\circ} \mathrm{C}$ and $400^{\circ} \mathrm{C}$ caused by the dehydration of the precipitate and the reduction of $\mathrm{Mn}$.

Iron precipitate. Both goethite $(\alpha-\mathrm{FeOOH})$ and lepidocrocite $(\gamma-\mathrm{FeOOH})$ were identified in the $\mathrm{Fe}$ precipitate (Fig. 6; for chemical composition see Table 3, No. 2). Goethite is the stabler polymorph and is generally formed in areas of temperate humid climate. Lepidocrocite has been identified in the same climatic zone but its occurrence is restricted to hydromorphic soils (Brown 1953, Schwertmann 1959, Pawluk 1971, Koljonen et al. 1976, 
Schwertmann and Fitzpatrick, in press) where $\mathrm{Fe}$ is reduced under anaerobic conditions. The occurrence of lepidocrocite thus testifies to the presence of $\mathrm{Fe}^{2+}$.

The simultaneous crystallization of goethite and lepidocrocite in soils is not fully understood. Synthesis experiments show that somewhat higher partial pressure of $\mathrm{CO}_{2}$ favors goethite formation at the expense of lepidocrocite when ferrous solutions are oxidized (Schwertmann 1959, Schwertmann and Fitzpatrick, in press), goethite possibly being formed via carbonate $\left(\mathrm{FeCO}_{3}\right)$ and lepidocrocite via "green rust» (Fe(II,III) hydroxy compound) (Schwertmann et al. 1974). The complexation of $\mathrm{Fe}$ with organic ligands is known to favor the precipitation of goethite out of ferric solutions (Schwertmann et al. 1974).

Lepidocrocite and goethite have been found together in a similar environment to that studied (Koljonen et al. 1976): $\mathrm{Mn}$ and Fe were there precipitated out of ground water, rich in organic matter and reducing, at the point where the ground water came in contact with the atmosphere. A separate study to clarify what controls the simultaneous formation of goethite and lepidocrocite in soils and what are the roles of dissolution and interconversion is presently underway.

Goethite and lepidocrocite consist of $\mathrm{Fe}$ centred oxygen/hydroxyl octahedra linked together to form double chains in goethite and layers in lepidocrocite. Goethite is generally the less crystalline of the two (Schwertmann and Fitzpatrick, in press) as shown by line broadening on the X-ray diffractogram (Fig. 6; Koljonen et al. 1976). Goethite is the stabler polymorph and lepidocrocite shows a tendency to be converted to it. The conversion proceeds via solution (Schwertmann and Taylor 1972a,b), and the foreign compounds present in soils may interfere with it. The solubility and dissolution rate of lepidocrocite is low, especially when its crystallinity is high, but is increased in the presence of ferrous iron, i.e., in a reducing environment. Laboratory experiments have proved that organic compounds and silica prevent the nucleation of goethite and thus the transformation of lepidocrocite into it (Schwertmann and Fitzpatrick, in press), but this cannot be the rate-determining factor in a system that contains goethite (Schwertmann and Taylor 1972b).

Upon heat treatment, goethite and the amorphous fraction present are converted via dehydration and rearrangement to hematite $\left(\alpha-\mathrm{Fe}_{2} \mathrm{O}_{3}\right)$. The conversion temperature varies with the crystallinity of goethite, and is lowest for the amorphous hydroxide form. Temperatures between $300^{\circ} \mathrm{C}$ and $400^{\circ} \mathrm{C}$ are usually reported (Tosson et al. 1974, Kodama et al. 1977). Lepidocrocite is converted to maghemite $\left(\gamma-\mathrm{Fe}_{2} \mathrm{O}_{3}\right)$ at temperatures corresponding to the conversion of poorly crystallized goethite to hematite (Kelly 1956). Maghemite is readily converted to hematite upon further heating and can hardly be detected by X-ray diffraction. The first hematite reflections to appear are those shifted slightly from the position in hydrous to the position in anhydrous forms (Francombe and Rooksby 1959), indicating a similar recrystallization via partial decomposition of the parent structure (cf., Feitknecht et al. 1973) as proposed for Mn oxyhydroxides. Upon further heating the hematite crystals grow and become more ordered (Fig. 6).

\section{Chemical composition}

The chemical composition of the $\mathrm{Mn}, \mathrm{Fe}$ precipitate discussed in this paper is presented in Tables 3 and 4.

$\mathrm{Mn}$ is enriched in sample No. 1 and Fe in samples Nos. 2 and 3. Besides $\mathrm{Mn}$ and Fe the 
precipitate contains other cations, especially ones that form hydroxides in neutral environment. They too are zonally precipitated around the water discharge, as can be seen in the high $\mathrm{Al}, \mathrm{Mg}$, and $\mathrm{Ti}$ content of sample No. 3 and its lighter color compared with sample No. 2. Calcium predominates in ground water (Table 3 , No. 4) but, compared with magnesium, is depleted in the precipitate. This occurs because it neither forms hydroxides nor enters the lattice of the $\mathrm{Mn}$ and Fe minerals. Potassium is bound more strongly than sodium on colloids and its content in the precipitate is higher (cf., Koljonen and Carlson 1975). Many elements are enriched with oxidates (e.g., Cronan and Thomas 1972) and the contents of $\mathrm{Pb}, \mathrm{Ni}, \mathrm{Co}$, $\mathrm{Zn}, \mathrm{Cu}, \mathrm{Cd}$, and $\mathrm{REE}$ are increased in the precipitate. Compared with $\mathrm{K}, \mathrm{Rb}$ is depleted. The $\mathrm{K} / \mathrm{Rb}$ ratio, which in continental rock types only rarely falls outside 160-300 (Heier and Billings 1970), is here appreciably higher (790-3000, Table 3). This indicates the precipitation of solid phases which can incorporate $\mathrm{K}$. If adsorption alone had determined the $\mathrm{K}$ and $\mathrm{Rb}$ contents the latter would be enriched because of its relatively stronger adsorption on colloids, and the $\mathrm{K} / \mathrm{Rb}$ ratio would be lower than found (Table 3 ).

The precipitate studied contains more Sn, $\mathrm{Pb}$, and $\mathrm{Cd}$ than oceanic $\mathrm{Mn}, \mathrm{Fe}$ nodules (Table 3; Bender 1972). This difference probably occurs because the bedrock and sediments in the studied area are mostly silicic and the elements mentioned are enriched in the late differentiates of the calc-alkalic suite. The contents of $\mathrm{Ni}, \mathrm{Co}$, and $\mathrm{Cu}$ are much lower than in oceanic nodules.

Because the $\mathrm{Mn}$ and Fe precipitates have been formed close to each other, from running water, their different trace element composition cannot be due to differences in the precipitating solution. The analyses show that $\mathrm{Ti}$ and $\mathrm{Cr}$ are enriched more in the Fe-rich cement (Nos. 2 and 3) and $\mathrm{Ni}$ and $\mathrm{Cu}$ more in the Mn-rich (No. 1). Na, $\mathrm{Co}, \mathrm{Zn}, \mathrm{Rb}, \mathrm{Li}$, and $\mathrm{REE}$ show no preference for one or the other.

REE are enriched in the studied precipitate, but not as much as in oceanic nodules (Table 4). The contents are higher than in common magmatic (e.g., granites, REE 237 ppm, La/ $\mathrm{Yb} \sim 10$, Koljonen and Rosenberg 1976) and metamorphic rocks or in clastic sediments (see Ronov et al. 1974). The $\mathrm{La} / \mathrm{Yb}$ ratio (23-41, Table 4) is higher than in common rock and sediment types $(\sim 1-20$, see Koljonen and Rosenberg 1976), indicating that during the exogenic migration the REE differentiate from each other, the heavy REE $(\mathrm{Gd}-\mathrm{Lu})$ migrating faster than the light $(\mathrm{La}-\mathrm{Sm})$. This seems to be a general rule which controls the migration of REE and brings about the enrichment of light REE in the continents during the evolution of Earth's crust.

The $\mathrm{La} / \mathrm{Yb}$ ratio of oxidates reflects the ratio in the surrounding bedrock and sediments. It is much lower in oceanic nodules than in the precipitate studied (Table 4). The rocks in oceanic environment usually have lower $\mathrm{REE}$ contents and $\mathrm{La} / \mathrm{Yb}$ ratio $(\sim 1)$ than those in continents $(\sim 10)$ (see Koljonen and Rosenberg 1975, Table 2).

Compared with $\mathrm{La}$ and $\mathrm{Nd}$, the Ce content is increased in Fennoscandian Mn, Fe precipitates (Table 4, No. 5) and in oceanic nodules (No. 6; see Goldberg 1961) but not in the studied samples (Nos. 1-3). It seems that the Ce enrichment, common in oxidates, is brought about through dissolving and therefore is not observed in young precipitates. In solution Ce probably has the valence $3+$ like the other REE and behaves upon precipitation like them. The normalized graph of a newly formed oxidate is smooth (Fig. 7). Unlike the other REE, however, Ce is oxidized to valence $4+$, does not dissolve 


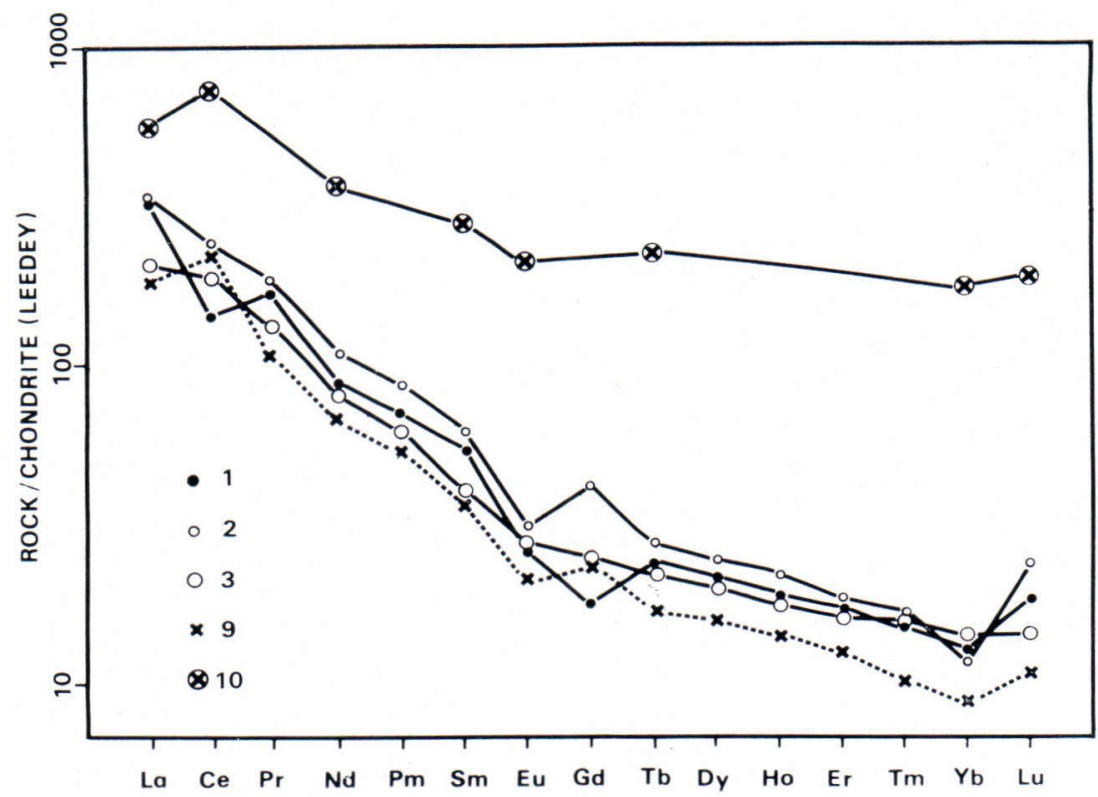

Fig. 7. REE contents normalized against chondrite (Leedey). The numbers in the graph indicate the analyses shown in Table 4 .

as quickly, and is enriched upon partial dissolution of the precipitate. This suggests that the chemical composition of oxidates depends not only on the chemical composition of the surrounding solutions but is to a large extent affected by dissolution. Accordingly, it depends on the relative dissolution rate of individual elements and on the chemical composition of minerals and other solid phases present in the precipitate. The chemical composition of a precipitate thus depends considerably on its age and the chemical processes it has undergone after precipitation.

\section{Discussion}

The present precipitate was formed in an esker surrounded by vast expanses of clay ana silt. In an environment like that, $\mathrm{Mn}$ and $\mathrm{Fe}$ are dissoived and migrate with ground water as organic complexes and as $\mathrm{Mn}^{2+}$ and $\mathrm{Fe}^{2+}$ (Koljonen et al. 1976). Their precipitation is controlled by the redox conditions of the environment. $\mathrm{Fe}$ is oxidized and precipitated before $\mathrm{Mn}$ where Eh and $\mathrm{pH}$ gradually increase (Krauskopf 1957). In the present case Mn has precipitated before $\mathrm{Fe}$ as a rim around the ground-water discharge, and $\mathrm{Fe}$ outside it. This order of precipitation can be explained as follows. When ground water flows fast to the surface the Eh is abruptly increased, so that the order of precipitation is controlled by the different stabilities of the $\mathrm{Mn}$ - and Fe-organic complexes, which control the reaction velocity; the Fe-complexes are known to be more stable than the Mn-complexes (Schnitzer and Hansen 1970). Mn and Fe are well separated from each other in the present precipitation, which in a young precipitate cannot be the result of diffusion in solid state (cf. Carlson et al., in press).

The $\mathrm{Mn}$ and $\mathrm{Fe}$ precipitates studied are oxyhydroxides which only partly occur as 
identifiable crystals. The reflections of birnessite, goethite, and lepidocrocite on the $\mathrm{X}$-ray graphs are weak and broadened. Besides $\mathrm{Mn}$ and Fe the precipitate contains other cations, which either are incorporated in the lattice of minerals (birnessite), form their own hydroxides (Al, Mg; Table 3, No. 3 ), or are adsorbed on colloids ( $\mathrm{Rb}, \mathrm{Li})$. Upon heat treatment the precipitates are dehydrated and the minerals broken into separate layers and fragments according to their crystal structure. Upon further heating they are recrystallized as oxides and spineis in accordance with the overall chemical composition of the precipitate.

Many trace elements are enriched in the precipitate. The trace element composition clearly reflects that found in the surrounding, mostly silicic bedrock. The REE content, for example, is increased, and although the total content is lower than in oceanic $\mathrm{Mn}$ nodules the $\mathrm{La} / \mathrm{Yb}$ ratio is much higher, indicating a greater enrichment of the light $\operatorname{REE}(\mathrm{La}-\mathrm{Sm})$ than of the heavy $(\mathrm{Gd}-\mathrm{Lu})$. This seems to be a general rule and is brought about by a greater adsorption on colloids of the light than of the heavy REE, probably because of their greater ionic radius. Thus the $\mathrm{La} / \mathrm{Yb}$ ratio increases with time in continents and the ratio, on average, is higher in continental sediments and rocks derived from them than in oceanic.

The content of Ce in relation to $\mathrm{La}, \mathrm{Pr}$, and $\mathrm{Nd}$ reflects the age of an oxidate and its mode of formation via precipitation and partial dissolution. Because Ce can be oxidized to higher valence than the other REE it tends to migrate more slowly and is depleted in solutions. The residence time of $\mathrm{Ce}$ in ocean water is much shorter than that of the other REE and it is depleted there (Herrmann 1970) but enriched in oceanic Mn nodules. The enrichment of Ce in continental sediments also helps to bring about the depletion in oceanic water. Moreover, geochemical differentiation apparently occurs during the exogenic migration of REE, causing the various $\mathrm{REE}$ to be unequally distributed among the different sediment groups.

Acknowledgements - The Institute of Biology and Geology, University of Tromsø, put the X-ray diffractometer at our disposal. Thermal and chemical analyses were made at the Institute of Geology, University of Helsinki; water analyses at the Geological Survey of Finland; and REE analyses at the Reactor Laboratory, Technical Research Centre of Finland. We thank the personnel of these institutions for their cooperation, and Prof. Dr. U. Schwertmann for his comments on the manuscript.

\section{REFERENCES}

Alhonen, P., Koljonen, T., Lahermo, P., and Uusinoka, R. (1975) Ferruginous concretions around root channels in clay and fine sand deposits. Bull. Geol. Soc. Finland 47: 175-181.

Bender, M. L. (1972) Manganese nodules. Pp. 673677 in The Encyclopedia of Geochemistry and Environmental Sciences, ed by R. W. Fairbridge. van Nostrand Reinhold Company, New York.

Bricker, O. (1965) Some stability relations in the system $\mathrm{Mn}-\mathrm{O}_{2}-\mathrm{H}_{2} \mathrm{O}$ at $25^{\circ}$ and one atmosphere total pressure. Am. Mineral. 50: 1296-1354.
Brown, F. H., Pabst, A., and Sawyer, D. L. (1971) Birnessite on colemanite at Boron, California. Am. Mineral. 56: 1057-1064.

Brown, G. (1953) The occurrence of lepidocrocite in some British soils. J. Soil Sci. 4: 220-228.

Carlson, L., Koljonen, T., and Vuorinen, A. (in press) The precipitation of iron and manganese in Fennoscandia: Geology and geochemistry. Proc. $3^{\text {rd }}$ Int. Symp. Environ. Biogeochem., Wolfenbüttel, 1977.

Crerar, D. A. and Barnes, H. L. (1974) Deposition 
of deep-sea manganese nodules. Geochim. Cosmochim. Acta 38: 279-300.

Cronan, D. S. and Thomas, R. L. (1972) Geochemistry of ferromanganese oxide concretions and associated deposits in Lake Ontario. Geol. Soc. Am. Bull. 83: 1493-1502.

Feitknecht, W., Giovanoli, R., Michaelis, W., and Müller, M. (1973) Über die Hydrolyse von Eisen(III)Salzlösungen. I. Die Hydrolyse der Lösungen von Eisen(III)chlorid. Helv. Chim. Acta 56: 2847-2856.

Francombe, $M$. $H$. and Rooksby, H. P. (1959) Structure transformations effected by the dehydration of diaspore, goethite and delta ferric oxide. Clay Miner. Bull. 4: 1-14.

Giovanoli, R. and Bürki, P. (1975) Comparison of $\mathrm{X}$-ray evidence of marine manganese nodules and non-marine manganese ore deposits. Chimia 29: 266-269.

Giovanoli, R. and Stähli, E. (1970) Oxide und Oxidhydroxide des drei- und vierwertigen Mangans. Chimia 24: 49-61.

Giovanoli, R., Stähli, E., and Feitknecht, W. (1970a) Über Oxidhydroxide des vierwertigen Mangans mit Schichtengitter. 1. Mitteilung: Natriummangan(II,III)manganat(IV). Helv. Chim. Acta 53: $209-220$.

Giovanoli, R., Stähli, E., and Feitknecht, W. (1970b) Über Oxidhydroxide des vierwertigen Mangans mit Schichtengitter. 2. Mitteilung: Mangan(III)manganat(IV). Helv. Chim. Acta 53: 453-464.

Glover, E. D. (1977) Characterization of a marine birnessite. Am. Mineral. 62: 278-285.

Goldberg, E. D. (1961) Chemistry in the oceans. Pp. 583-597 in Oceanography, ed. by M. Sears. Am. Ass. Adv. Sci., Publ. 67.

Heier, K. S. and Billings, G. K. (1970) Rubidium, 37 - E. Abundance in common magmatic rock types; Terrestrial abundance. V. K/Rb ratios. In Handbook of Geochemistry, ed. by $\mathrm{K}$. $\mathrm{H}$. Wedepohl. Springer-Verlag, Berlin and Heidelberg.

Herrmann, A. G. (1970) Yttrium and lanthanides, 39, 57-71-I. Abundance in natural waters. In Handbook of Geochemistry, ed. by $\mathrm{K}$. $\mathrm{H}$. Wedepohl. Springer-Verlag, Berlin and Heidelberg.

van Hook, H. J. and Keith, M. L. (1958) The system $\mathrm{Fe}_{3} \mathrm{O}_{4}-\mathrm{Mn}_{3} \mathrm{O}_{4}$. Am. Mineral. 43: 6983.

Jones, L. H. P. and Milne, A. A. (1956) Birnessite, a new manganese oxide mineral from Aber- deenshire, Scotland. Mineral. Mag. 31: 283288.

Kelly, W. C. (1956) Application of differential thermal analysis to identification of the natural hydrous ferric oxides. Am. Mineral. 41: 353355 .

Kcdama, H., McKeague, J. A., Tremblay, R. J., Gosselin, J. R., and Townsend, M. G. (1977) Characterization of iron oxide compounds in soils by Mössbauer and other methods. Can. J. Earth Sci. 14: 1-15.

Koljonen, T. and Carlson, L. (1975) Behaviour of the major elements and minerals in sediments of four humic lakes in south-western Finland. Fennia 137.

Koljonen, T., Lahermo, P., and Carlson, L. (1976) Origin, mineralogy, and chemistry of manganiferous and ferruginous precipitates found in sand and gravel deposits in Finland. Bull. Geol. Soc. Finland 48: 111-135.

Koljonen, T. and Rosenberg, R. J. (1975) Rare earth elements in Middle Precambrian volcanic rocks of Finland, with a discussion of the origin of the rocks. Bull. Geol. Soc. Finland 47: 127138.

Koljonen, T. and Rosenberg, R. J. (1976) Major elements and REE in tektites and three probable shock-metamorphic rock series of the Baltic shield. Geochem. J. 10: 1-11.

Krauskopf, K. B. (1957) Separation of manganese from iron in sedimentary processes. Geochim. Cosmochim. Acta 12: $61-84$.

Låg, J. (1960) A special type of hardpan, rich in manganese. Sci. Rep. Agric. Coll. Norway 39: $1-7$.

Masuda, A., Nakamura, N., and Tanaka, T. (1973) Fine structures of mutually normalized rareearth patterns of chondrites. Geochim. Cosmochim. Acta 37: 239-248.

Muan, A. and Somiya, S. (1962) The system iron oxide - manganese oxide in air. Am. J. Sci. 260: $230-240$.

Munsell Color Comp. (1975) Soil Color Charts. Baltimore.

Pawıuk, S. (1971) Characteristics of Fera eluviated gleysols developed from acid shales in northwestern Alberta. Can. J. Soil Sci. 51: 113-124.

Piper, D. Z. (1974) Rare earth elements in ferromanganese nodules and other marine phases. Geochim. Cosmochim. Acta 38: 1007-1022.

Ronov, A. B., Balashov, Yu. A., Girin, Yu. P., Bratishko, R. Kh., and Kazakov, G. A. (1974) Regularities of rare-earth element distribution 
in the sedimentary shell and in the crust of the earth. Sedimentology 21: 171-193.

Rosenberg, R. J. (1977) Instrumental neutron activation analysis as a routine method for rock analysis. Tech. Res. Cent. Finland, Electr. Nucl. Technol., Publ. 19.

Ross, S. J., Jr., Franzmeier, D. P., and Roth, C. B. (1976) Mineralogy and chemistry of manganese oxides in some Indiana soils. Soil Sci. Soc. Am. J. 40: 137-143.

Schnitzer, M. and Hansen, E. H. (1970) Organometallic interactions in soils: 8 . An evaluation of methods for the determination of stability constants of metal-fulvic acid complexes. Soil Sci. 109: $333-340$.

Schwertmann, U. (1959) Die fraktionierte Extraktion der freien Eisenoxyde in Böden, ihre mineralogischen Formen und ihre Entstehungsweisen. Z. Pflanzenernähr. Düng. Bodenkd. 84: $194-204$.

Schwertmann, U., Fischer, W. R., and Taylor, R. $M$. (1974) New aspects of iron oxide formation in soils. $10^{\text {th }}$ Int. Congr. Soil Sci., Moscow, 6: $237-249$.

Schwertmann, U. and Fitzpatrick, R. W. (in press) Occurrence of lepidocrocite and its association with goethite in Natal soils.

Schwertmann, U. and Taylor, R. M. (1972a) The transformation of lepidocrocite to goethite. Clays Clay Miner. 20: 151-158.
Schwertmann, U. and Taylor, R. M. (1972b) The in vitro transformation of soil lepidocrocite to goethite. Pseudogley and gley. Int. Soc. Soil Sci., Trans. Comm. V, VI: 45-54.

Summerhayes, C. P. and Willis, J. P. (1975) Geochemistry of manganese deposits in relation to environment on the sea floor around southern Africa. Mar. Geol. 18: 159-173.

Taylor, R. M. (1968) The association of manganese and cobalt in soils - further observations. J. Soil Sci. 19: $77-80$.

Taylor, R. M. and McKenzie, R. M. (1966) The association of trace elements with manganese minerals in Australian soils. Aust. J. Soil Res. 4: $29-39$.

Taylor, R. M., McKenzie, R. M., and Norrish, K. (1964) The mineralogy and chemistry of manganese in some Australian soils. Aust. J. Soil Res. 2: 235-248.

Tosson, S., El-Mahdy, O. R., and Saad, N. A. (1974) Differential thermal and thermogravimetric analyses of the Bahariya iron ore deposits, Egypt. Bull. Soc. Fr. Mineral. Cristallogr. 97: $27-39$.

Vasari, Y., Koljonen, T., and Laakso, K. (1972) A case of manganese precipitate in the Taviharju esker, Kuusamo, North East Finland. Bull. Geol. Soc. Finland 44: 133-140.

Manuscript received October 30, 1977. 